Resumo

\title{
Comparação da transmissão de força entre o calçado militar e o calçado esportivo
}

Pedro Afonso dos Santos Júnior Bsci, Rodrigo Rico Bini PhD

Introdução: Tendo em vista a ampla gama de opções de calçados destinados a realização da atividade física, há necessidade do conhecimento das implicações do uso destes durante o exercício.

Objetivo: 0 objetivo desse estudo foi analisar e comparar a transmissão da força de reação do solo durante a fase de saída do pé na marcha com a utilização de um coturno e um tênis militar.

Métodos: 0 estudo envolveu a participação de 10 militares saudáveis e sem sintomas ou lesões musculoesqueléticas que interferissem na marcha. Os participantes realizaram três testes de avaliação da marcha, consistindo na caminhada em velocidade controlada de $5 \pm 0,25 \mathrm{~km} / \mathrm{h}$, sobre uma passarela nivelada de madeira onde duas plataformas de força captaram os componentes da força de reação do solo. Em cada teste, os participantes realizaram 10 passagens descalços, 10 passagens com o tênis militar e 10 passagens com o coturno. A transmissão de força entre o solo e o solado dos calçados foi determinada a partir da maior variação da força de reação do solo durante a fase de propulsão, sendo esta medida equalizada pela transmissão de força mensurada durante a caminhada sem o uso do calçado. Após a verificação e confirmação da normalidade na distribuição dos dados, a transmissão de força foi comparada utilizando teste t de Student para amostras não-pareadas, com análise bilateral, sendo associados à avaliação da magnitude das diferenças (effect sizes - ES), realizada segundo Cohen. Efeitos substanciais foram considerados quando grandes magnitudes de diferença $(E S>0,8)$ e $p<0,05$ foram observados.

Resultados: A velocidade durante a caminhada no teste não diferiu entre os testes descalço e com tênis militar ( $p=0,20$ e $E S=0,60)$, entre o coturno e descalço $(p=0,43$ e $E S=0,37)$ e entre os participantes que estavam com o tênis militar e de coturno ( $p=0,43$ e $E S=0,38)$. Também, não houve diferença para a transmissão de força durante a fase de saída do pé do solo ( $p=0,10$ e $E S=0,50)$. Conclusão: A transmissão de força de reação do solo durante a fase de saída do pé do solo não apresentou diferenças significantes entre o tênis e o coturno fornecido pela cadeia de suprimento, se assemelhando durante a marcha. 